\title{
Micellar liquid chromatographic analysis of benzyl alcohol and benzaldehyde in injectable formulations
}

MOHAMED RIZK

FAWZIA IBRAHIM

MOHAMED HEFNAWY

JENNY JEEHAN NASR*

Faculty of Pharmacy, Department of Analytical Chemistry, University of Mansoura, Mansoura-35510, Egypt

Accepted February 5, 2007
An accurate, sensitive and selective reversed-phase micellar liquid chromatographic method was developed for simultaneous determination of benzyl alcohol and benzaldehyde. This method was applied in different injectable formulations containing diclofenac, piroxicam, lincomycin and clindamycin. The method showed excellent linearity in the range of $10-100 \mu \mathrm{g} \mathrm{mL}^{-1}$ and $1-20 \mu \mathrm{g} \mathrm{mL}$ with the limit of detection $(\mathrm{S} / \mathrm{N}=3) 0.25 \mu \mathrm{g} \mathrm{mL}^{-1}(2.3 \times$ $\left.10^{-6} \mathrm{~mol} \mathrm{~L}^{-1}\right)$ and $0.12 \mu \mathrm{g} \mathrm{mL}-1\left(1.13 \times 10^{-6} \mathrm{~mol} \mathrm{~L}^{-1}\right)$ for benzyl alcohol and benzaldehyde, respectively. The suggested method was successfully applied to the analysis of the studied drugs in bulk with average recoveries of $100.1 \pm 1.0 \%$ for benzyl alcohol and $100.4 \pm 1.6 \%$ for benzaldehyde, and to the determination of benzyl alcohol and benzaldehyde in injectable formulations with the respective average recoveries of $99.8 \pm 0.3$ and $100.0 \pm 0.4 \%$.

Keywords: micellar liquid chromatography, benzyl alcohol, benzaldehyde, injectable formulations

Benzyl alcohol is frequently used as an antimicrobial preservative or co-solvent in a variety of pharmaceutical injection formulations. The main toxic oxidation product, benzaldehyde, arises from the oxidation of benzyl alcohol upon long-term storage or heat sterilization of parenteral dosage forms containing benzyl alcohol, if oxygen is not excluded by nitrogen flushing. The presence of this potential impurity needs to be monitored owing to its reactivity and toxicity (1).

Several methods have been reported for the quantitative determination of benzyl alcohol in parenterals, which include spectrophotometry $(2,3)$, gas chromatography $(4,5)$, HPLC $(4,6,7)$. The United States Pharmacopoeia (8) limits the presence of benzaldehyde in benzyl alcohol to a level of $0.2 \%$, when determined by the HPLC method.

The British Pharmacopoeia (9) states that benzyl alcohol intended for use in the manufacture of parenteral dosage forms should not contain more than $0.05 \%$ benzaldehyde and describes a GC method for its determination in the raw material. Different methods

\footnotetext{
*Correspondence, e-mail: nasrjj@yahoo.com
} 
for benzaldehyde determination in benzyl alcohol include gas chromatography $(10,11)$ and liquid chromatographic methods $(12,13)$ as well as UV spectrometry $(14-16)$ and polarography (1).

In the present work, a new approach was achieved for the analysis of this preservative with or without its degradation product, benzaldehyde, by micellar liquid chromatography. Different chromatographic conditions were studied in an attempt to optimize a simple, sensitive and selective method for the evaluation of the studied compounds in bulk and dosage forms.

\section{EXPERIMENTAL}

\section{Materials and reagents}

Benzyl alcohol (Ubichem, UK), benzaldehyde, o-phosphoric acid (Prolabo, France) propyl paraben (Sedico, Egypt) are all analytical reagents. Methanol (Hipersolv, Merck, Germany), 1-propanol and triethylamine (TEA) (Riedel-deHäen, Germany) are HPLC grade reagents. Sodium dodecyl sulphate (SDS) 99\% purity (Park, Scientific Limited, UK), piroxicam raw material $99.2 \%$ purity and diclofenac sodium raw material $99.5 \%$ purity (Sedico) were also used.

Injectable formulations investigated are (A) Feldene ${ }^{\circledR}$ (Pfizer, Egypt), (B) Dispercam $^{\circledR}$ (Medical Union Pharmaceuticals, Egypt), both containing $20 \mathrm{mg} \mathrm{mL}^{-1}$ benzyl alcohol. (C) Feldoral ${ }^{\circledR}$ (Sedico, Egypt), (D) Voltaren ${ }^{\circledR}$ (Novartis, Egypt), both containing 40 $\mathrm{mg} \mathrm{mL}^{-1}$ benzyl alcohol, (E) Rheumarene ${ }^{\circledR}$ (Sedico, Egypt) containing $50 \mathrm{mg} \mathrm{mL}^{-1}$ benzyl alcohol, (F) Lincocin ${ }^{\circledR}$ and $(\mathrm{G})$ Dalacin $\mathrm{C}^{\circledR}$ (Memphis, Egypt), both containing $9 \mathrm{mg}$ $\mathrm{mL}^{-1}$ benzyl alcohol.

\section{Chromatographic conditions}

Chromatographic analyses were carried out using a chromatograph model L-7100 (Merck Hitachi, Germany) equipped with an injector valve with a $20-\mu \mathrm{L}$ loop (Rheodyne, USA), a L-7400 UV detector (Merck Hitachi). The chromatograms were recorded on a D-7500 integrator (Merck Hitachi). Mobile phase was degassed using a Merck solvent L-7612 degasser.

Apex ODS-2, C18 column (120 mm $\times 4.6 \mathrm{~mm}$ i.d., $5 \mu \mathrm{m})$ was used. The mobile phase used for investigation was a solution containing $0.07 \mathrm{~mol} \mathrm{~L}^{-1}$ sodium dodecyl sulphate and 10\% 1-propanol and $0.3 \%$ triethylamine in $0.02 \mathrm{~mol} \mathrm{~L}^{-1}$ phosphoric acid of $\mathrm{pH} 7.5$. The flow rate was $1 \mathrm{~mL} \mathrm{~min}^{-1}$ and the detection wavelength was $254 \mathrm{~nm}$. The internal standard was propyl paraben.

\section{Calibration}

Stock solutions of $0.4 \mathrm{mg} \mathrm{mL}^{-1}$ benzyl alcohol and benzaldehyde were prepared in methanol. Working solutions $10-100 \mu \mathrm{g} \mathrm{mL}^{-1}$ and 1-20 $\mathrm{g} \mathrm{mL}^{-1}$ of benzyl alcohol and benzaldehyde, respectively, were injected together with internal standard $\left(5 \mu \mathrm{g} \mathrm{mL}^{-1}\right.$ of propyl paraben, prepared from the stock solution of $\left.0.04 \mathrm{mg} \mathrm{mL}^{-1}\right) .20 \mu \mathrm{L}$ aliquots were 
injected (triplicate) and eluted with the mobile phase under the reported chromatographic conditions. The average peak height ratio between the internal standard and benzyl alcohol or benzaldehyde vs. the concentration of benzyl alcohol or benzaldehyde was plotted.

\section{Analysis of bulk substance and dosage forms}

The method mentioned above was applied to the determination of the purity of the studied raw materials.

Injectable solutions were diluted with methanol to contain $0.4 \mathrm{mg} \mathrm{mL}^{-1}$ benzyl alcohol, then aliquots of these solutions were successively diluted with the mobile phase, internal standard was added and the procedure followed as described in the previous section.

The percentage recoveries were calculated by referring to the calibration graphs.

\section{RESULTS AND DISCUSSION}

Micellar liquid chromatography (MLC) represents an attractive alternative to conventional aqueous-organic mobile phases in analysis. The retention of solutes is modified by the composition of eluents (17). The proposed method permits separation and quantitation of benzyl alcohol and benzaldehyde in parenteral formulations.

\section{Optimization of chromatographic performances}

Different columns were tried for performance investigations including Zorbax Eclipse XDB-C8 column (150 $\mathrm{mm} \times 4.6 \mathrm{~mm}$ i.d., $5 \mu \mathrm{m}$ particle size) (Agilent, USA), Bondclone, C18 column ( $300 \mathrm{~mm} \times 3.9 \mathrm{~mm}$ i.d., $10 \mu \mathrm{m}$ particle size) (Phenomenex, USA), Apex ODS-2, C18 column (120 mm $\times 4.6 \mathrm{~mm}$ i.d., $5 \mu \mathrm{m}$ particle size) (Merck, Germany). The results obtained show that the third column was the most suitable one since a good resolution of peaks was obtained.

Fig. 1 shows a chromatogram indicating good resolution of benzyl alcohol $\left(t_{\mathrm{R}}=2.1\right.$ min) and benzaldehyde $\left(t_{\mathrm{R}}=3.8 \mathrm{~min}\right)$.

The UV detector response of benzyl alcohol and benzaldehyde was studied and the best wavelength was found to be $254 \mathrm{~nm}$, showing the highest sensitivity. The use of different internal standards such as methyl paraben and propyl paraben was studied to obtain accurate and elegant results. The use of methyl paraben was investigated and it was found to be unsuitable since it is poorly resolved from benzaldehyde. Propyl paraben is the internal standard of choice.

Several modifications in the micellar mobile phase composition were performed in order to study the possibilities of changing the selectivity of the chromatographic system. These modifications included the change of surfactant concentration, the concentration of co-surfactant, the $\mathrm{pH}$ and the flow rate (Fig. 1). The best $\mathrm{pH}$ for investigation was found to be 7.5 , since lower $\mathrm{pH}$ produced a shoulder in the required peak and at $\mathrm{pH}$ 6.0 a forked peak was produced. The effect of changing concentration of SDS on the selectivity and retention times of the test solutes was investigated using mobile phases containing SDS concentrations from 1-4\% $\left(0.05-0.15 \mathrm{~mol} \mathrm{~L}^{-1}\right)$. Fig. 1a shows that an increase in the SDS concentration will decrease retention. Concentration of $0.07 \mathrm{~mol} \mathrm{~L}^{-1}$ 

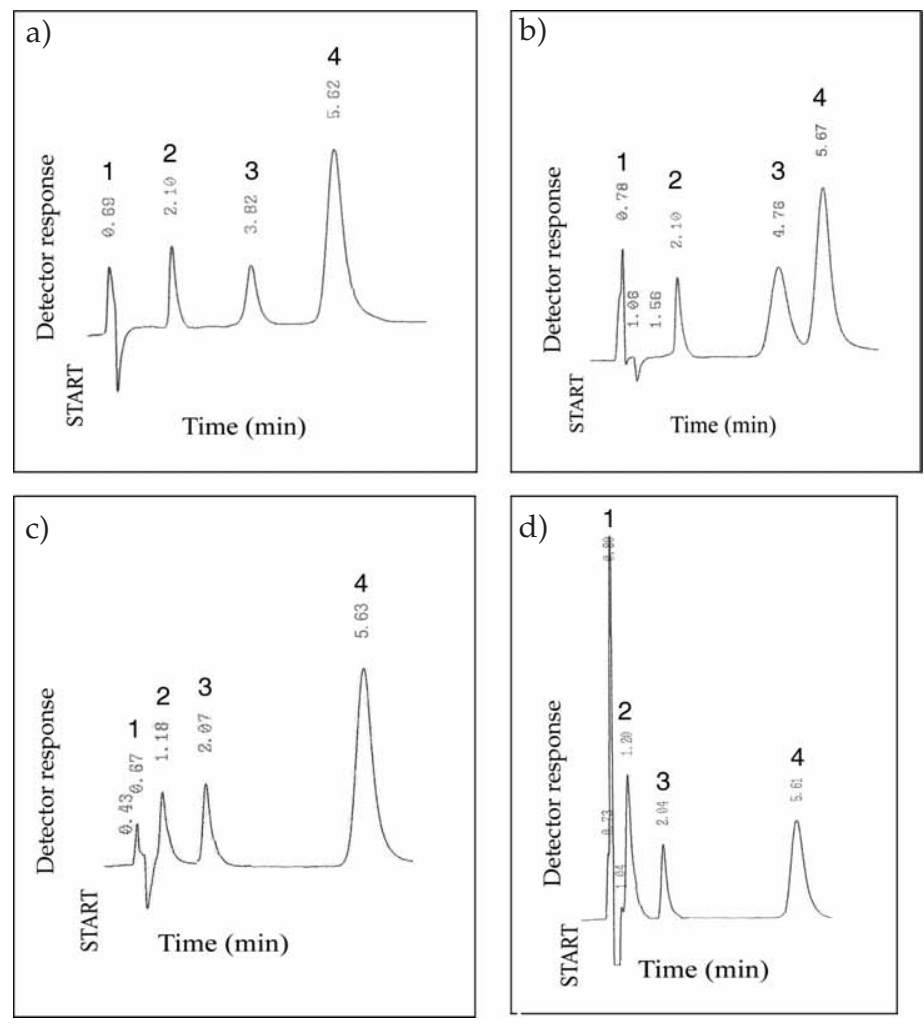

Fig. 1. Chromatograms showing:

a) 1 - solvent front

$2-40 \mu \mathrm{g} \mathrm{mL}^{-1}$ benzyl alcohol $\left(t_{\mathrm{R}}=2.1 \mathrm{~min}\right)$

$3-2 \mu \mathrm{g} \mathrm{mL}-1$ benzaldehyde $\left(t_{\mathrm{R}}=3.8 \mathrm{~min}\right)$

$4-5 \mu \mathrm{g} \mathrm{mL}-1$ propyl paraben $\left(t_{\mathrm{R}}=5.6 \mathrm{~min}\right)$

b) 1 - solvent front

$2-40 \mu \mathrm{g} \mathrm{mL}^{-1}$ benzyl alcohol $\left(t_{\mathrm{R}}=2.1 \mathrm{~min}\right)$

$3-25 \mu \mathrm{g} \mathrm{mL}^{-1}$ diclofenac sodium $\left(t_{\mathrm{R}}=5.7 \mathrm{~min}\right)$

$4-5 \mu \mathrm{g} \mathrm{mL}-1$ propyl paraben $\left(t_{\mathrm{R}}=5.6 \mathrm{~min}\right)$ c) 1 - solvent front

$2-1.33 \mathrm{mg} \mathrm{mL}^{-1}$ lincomycin $\left(t_{\mathrm{R}}=1.1 \mathrm{~min}\right)$

$3-40 \mu \mathrm{g} \mathrm{mL}^{-1}$ benzyl alcohol $\left(t_{\mathrm{R}}=2.1 \mathrm{~min}\right)$

$4-5 \mu \mathrm{g} \mathrm{mL}-1$ propyl paraben $\left(t_{\mathrm{R}}=5.6 \mathrm{~min}\right)$

d) 1 - solvent front

$2-60 \mu \mathrm{g} \mathrm{mL}-1$ piroxicam $\left(t_{\mathrm{R}}=1.2 \mathrm{~min}\right)$

$3-60 \mu \mathrm{g} \mathrm{mL}-1$ benzyl alcohol $\left(t_{\mathrm{R}}=2.1 \mathrm{~min}\right)$

$4-5 \mu \mathrm{g} \mathrm{mL}-1$ propyl paraben $\left(t_{\mathrm{R}}=5.6 \mathrm{~min}\right)$

(2\%) SDS was found to be suitable for routine work as it provides adequate elution time in addition to the best resolution and the highest number of theoretical plates. Fig. 1b shows the effect of changing the co-surfactant (1-propanol) concentration within the range of $6-15 \%$. The retention times of the test solutes decreased with increasing the co-surfactant concentration. The decrease is lower than that observed when changing the concentration of SDS and no significant effect on the selectivity is observed. A concentration of $10 \%$ was found to be suitable. The effect of flow rate on the formation and separation of peaks of the studied compounds was studied and a flow rate of $1 \mathrm{~mL} \mathrm{~min}-1$ was optimal for good separation in a reasonable time (Fig. 1c). 


\section{Figures of merit}

Under the above described experimental conditions, linear regression analysis of the data gave the following equations:

$$
\begin{aligned}
& \text { benzyl alcohol: } \text { PHR }=0.0158+0.011 \gamma(R=0.9999) \\
& \text { benzaldehyde }: \text { PHR }=0.089+0.133 \gamma(R=0.9999)
\end{aligned}
$$

where $\gamma$ is the concentration of the compound in $\mu \mathrm{g} \mathrm{mL}-1$ and PHR is the peak height ratio. The corresponding concentration ranges are 10-100 and 1-20 mg mL $\mathrm{mL}^{-1}$ for benzyl alcohol and benzaldehyde, respectively.

The high values of the correlation coefficients with small intercepts indicate good linearity of the calibration graphs. Statistical analysis of the data gave low values of the standard deviations of the residuals $\left(\mathrm{S}_{\mathrm{y} / \mathrm{x}}\right) 3.46 \times 10^{-3}$ and $9.11 \times 10^{-3}$, of slope $4.43 \times 10^{-5}$ and $5.3 \times 10^{-4}$, and of intercept $9.17 \times 10^{-4}$ and $5.21 \times 10^{-3}$ for benzyl alcohol and benzaldehyde, respectively.

The limit of detection $(L O D)$, defined as the analyte concentration giving a signal equal to the blank signal plus two standard deviations of the blank (18), was found to be $0.25 \mu \mathrm{g} \mathrm{mL}^{-1}\left(2.3 \times 10^{-6} \mathrm{~mol} \mathrm{~L}^{-1}\right)$ and $0.12 \mu \mathrm{g} \mathrm{mL}-1$ (1.13 $\left.\times 10^{-6} \mathrm{~mol} \mathrm{~L}^{-1}\right)$ for benzyl alcohol and benzaldehyde, respectively.

The limit of quantitation $(L O Q)$, which is the lowest amount of analyte in a sample that can be determined with acceptable precision and accuracy under the stated experimental conditions (8), was 0.83 and $0.40 \mu \mathrm{g} \mathrm{mL}^{-1}$ for benzyl alcohol and benzaldehyde, respectively.

The precision and accuracy of the proposed method were calculated using standard solutions containing three different concentrations of each benzyl alcohol and benzaldehyde (three replicates). The mean results obtained are summarized in Table I. Low relative standard deviation of up to $0.5 \%$ and $0.2 \%$ for benzyl alcohol and benzaldehyde, respectively, can be considered adequate for the quality control of pharmaceutical preparations. Accuracy expressed as recovery ranged from 99.5 to $100.6 \%$ for benzyl alcohol and from 98.2 to $100.7 \%$ for benzaldehyde, mean relative error was $0.1-0.6 \%$ and $0.1-$ $0.2 \%$ for benzyl alcohol and benzaldehyde, respectively.

\section{Dosage forms analysis}

The results of the proposed method were compared with those obtained from the official HPLC method (8). Statistical analysis of the results obtained by the proposed and official methods showed no significant difference between the performance of the two methods using Student's $t$ test and variance ratio $F$ values (Table II).

The proposed method was successfully applied to the assay of benzyl alcohol and benzaldehyde in different pharmaceutical preparations (injectable formulations). The average percent recoveries of different concentrations were based on the average of three replicate determinations. Recovery values ranged between 99.3 and $100.5 \%$ with RSD 0.2 $0.7 \%$ for both analytes in the presence of any of the four drugs (piroxicam, diclofenac, 
M. Rizk et al: Micellar liquid chromatographic analysis of benzyl alcohol and benzaldehyde in injectable formulations, Acta Pharm. 57 (2007) 231-239.

a)

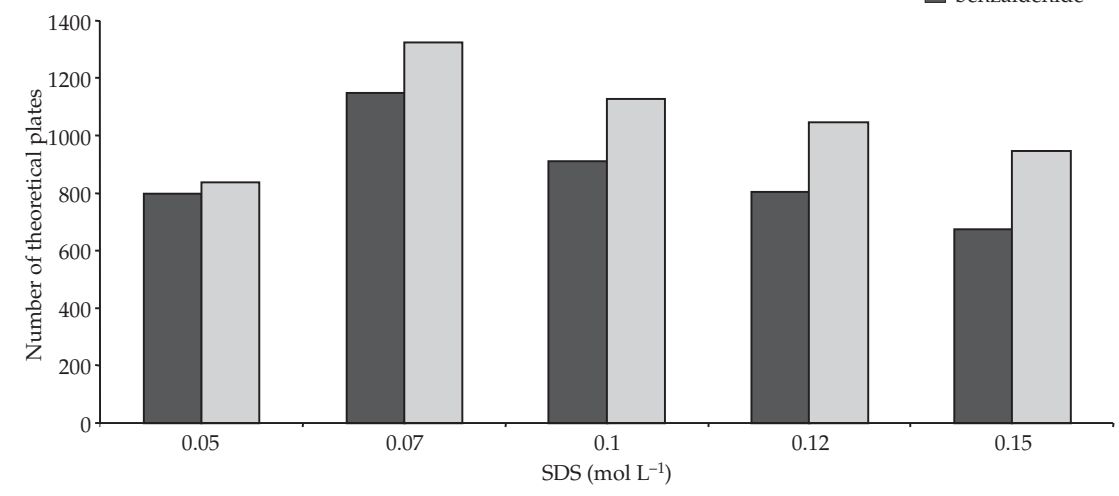

b)

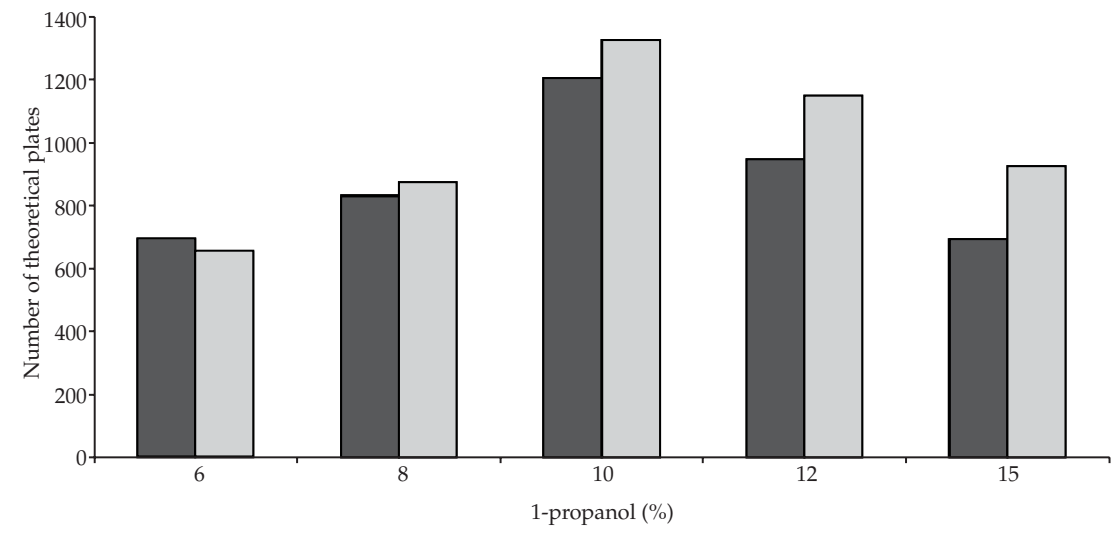

C)

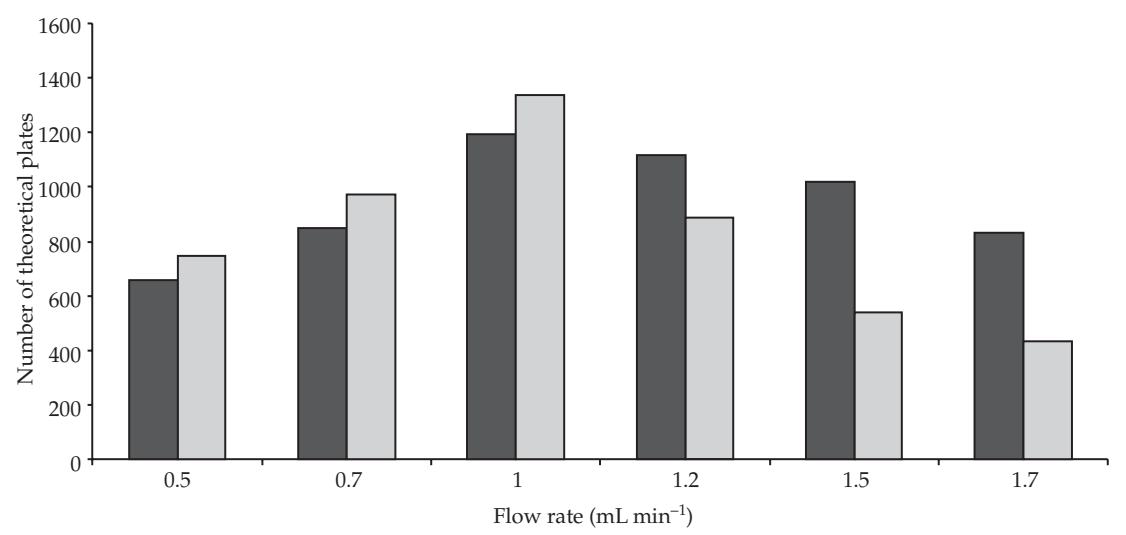

Fig. 2. Number of theoretical plates of benzyl alcohol and benzaldehyde as a function of: a) concentration of surfactant (SDS), b) concentration of cosurfactant (1-propanol), c) flow rate; - benzaldehyde, = benzylalcohol. 
M. Rizk et al.: Micellar liquid chromatographic analysis of benzyl alcohol and benzaldehyde in injectable formulations, Acta Pharm. 57 (2007) 231-239.

Table I. Accuracy and precision data for benzyl alcohol and benzaldehyde in standard solutions using the proposed method

\begin{tabular}{|c|c|c|c|c|c|c|c|}
\hline \multirow[b]{2}{*}{ Analyte } & \multirow{2}{*}{$\begin{array}{l}\text { Concentration } \\
\left(\mu \mathrm{g} \mathrm{mL} L^{-1}\right)\end{array}$} & \multicolumn{3}{|c|}{ Intra-day } & \multicolumn{3}{|c|}{ Inter-day } \\
\hline & & $\begin{array}{c}\text { Recovery } \\
(\text { mean } \pm \text { SD })^{\mathrm{a}}\end{array}$ & $\begin{array}{l}\text { RSD } \\
(\%)\end{array}$ & $\begin{array}{c}e_{r} \\
(\%)^{\mathrm{b}}\end{array}$ & $\begin{array}{c}\text { Recovery } \\
(\text { mean } \pm \text { SD) }\end{array}$ & $\begin{array}{l}\text { RSD } \\
(\%)\end{array}$ & $\begin{array}{c}e_{r} \\
(\%)^{\mathrm{b}} \\
\end{array}$ \\
\hline \multirow{3}{*}{$\begin{array}{l}\text { Benzyl } \\
\text { alcohol }\end{array}$} & 40.0 & $99.9 \pm 0.3$ & 0.3 & 0.1 & $99.9 \pm 0.7$ & 0.7 & 0.4 \\
\hline & 60.0 & $99.6 \pm 0.2$ & 0.2 & 0.1 & $99.8 \pm 1.0$ & 1.0 & 0.6 \\
\hline & 80.0 & $99.5 \pm 0.5$ & 0.5 & 0.3 & $100.6 \pm 0.8$ & 0.8 & 0.4 \\
\hline \multirow{3}{*}{ Benzaldehyde } & 5.0 & $98.2 \pm 0.2$ & 0.2 & 0.1 & $98.2 \pm 0.1$ & 0.1 & 0.1 \\
\hline & 10.0 & $100.0 \pm 0.1$ & 0.1 & 0.1 & $100.1 \pm 0.2$ & 0.1 & 0.1 \\
\hline & 12.0 & $100.7 \pm 0.1$ & 0.1 & 0.1 & $100.6 \pm 0.2$ & 0.1 & 0.1 \\
\hline
\end{tabular}

a $n=3$ at each concentration level.

b Mean relative error $(n=3)$.

Table II. Assay of benzyl alcohol and benzaldehyde in formulations using the proposed MLC and the official HPLC methods

\begin{tabular}{|c|c|c|c|c|c|}
\hline \multirow{2}{*}{ Analyte } & \multirow{2}{*}{ Formulation $^{\mathrm{a}}$} & \multicolumn{2}{|c|}{ Recovery $(\text { mean } \pm S D)^{b}$} & \multirow{2}{*}{$t$-value ${ }^{\mathrm{c}}$} & \multirow{2}{*}{$F$-value ${ }^{\mathrm{c}}$} \\
\hline & & Proposed method & Official method (8) & & \\
\hline \multirow[t]{7}{*}{ Benzyl alcohol } & A & $99.3 \pm 0.2$ & $100.1 \pm 0.7$ & 1.991 & 10.279 \\
\hline & B & $100.5 \pm 0.4$ & $99.9 \pm 0.4$ & 2.066 & 1.465 \\
\hline & $\mathrm{C}$ & $100.5 \pm 0.3$ & $100.0 \pm 0.5$ & 1.468 & 4.043 \\
\hline & $\mathrm{D}$ & $99.3 \pm 0.2$ & $100.0 \pm 0.6$ & 1.923 & 12.724 \\
\hline & $\mathrm{E}$ & $99.5 \pm 0.2$ & $100.1 \pm 0.5$ & 2.125 & 4.325 \\
\hline & $\mathrm{F}$ & $100.4 \pm 0.4$ & $100.6 \pm 0.3$ & 0.637 & 2.269 \\
\hline & G & $99.5 \pm 0.4$ & $100.3 \pm 0.6$ & 2.071 & 2.227 \\
\hline \multirow[t]{7}{*}{ Benzaldehyde } & A & $100.5 \pm 0.3$ & $100.1 \pm 0.6$ & 1.138 & 4.478 \\
\hline & B & $100.2 \pm 0.2$ & $100.2 \pm 0.5$ & 0.101 & 6.488 \\
\hline & $\mathrm{C}$ & $100.4 \pm 0.4$ & $100.1 \pm 0.4$ & 0.802 & 1.081 \\
\hline & $\mathrm{D}$ & $99.8 \pm 0.7$ & $100.9 \pm 0.8$ & 1.797 & 1.429 \\
\hline & $\mathrm{E}$ & $99.6 \pm 0.4$ & $100.2 \pm 0.4$ & 1.930 & 1.018 \\
\hline & $\mathrm{F}$ & $99.6 \pm 0.4$ & $100.1 \pm 0.6$ & 1.264 & 1.937 \\
\hline & G & $99.8 \pm 0.6$ & $99.9 \pm 0.6$ & 0.189 & 1.244 \\
\hline
\end{tabular}

\footnotetext{
a In A and B benzyl alcohol (20 $\left.\mathrm{mg} \mathrm{mL}^{-1}\right)$ is co-formulated with piroxicam.

In $C$ benzyl alcohol $\left(40 \mathrm{mg} \mathrm{mL}^{-1}\right)$ is co-formulated with piroxicam.

In $\mathrm{D}$ benzyl alcohol $\left(40 \mathrm{mg} \mathrm{mL}^{-1}\right)$ is co-formulated with diclofenac sodium.

In $\mathrm{E}$ benzyl alcohol $\left(50 \mathrm{mg} \mathrm{mL}^{-1}\right)$ is co-formulated with diclofenac sodium.

In F benzyl alcohol $\left(9 \mathrm{mg} \mathrm{mL}^{-1}\right)$ is co-formulated with lincomycin.

In $\mathrm{G}$ benzyl alcohol $\left(9 \mathrm{mg} \mathrm{mL}^{-1}\right)$ is co-formulated with clindamycin.

${ }^{\mathrm{b}} n=3$

c Tabulated $t$ - and $F$-values at $p=0.05$ are: $t=2.132$ and $F=19.00$.
} 
lincomycin, clindamycin). Fig. 1 shows chromatograms indicating good resolved peaks of benzyl alcohol in the presence of diclofenac sodium, lincomycin and piroxicam, respectively.

Degradation of benzyl alcohol to benzaldehyde is easily detectable and can be analyzed quantitatively, but the allowable limit is hardly detectable in injectable formulations. However, the standard addition technique can be followed to detect such minute amounts, if present.

\section{CONCLUSIONS}

The present investigation confirms that the use of micellar mobile phases in HPLC provides separation efficiency and selectivity comparable to conventional reversed-phase HPLC systems for the determination of benzyl alcohol and benzaldehyde in the studied formulations. The proposed procedure offers additional advantages over the official procedure, in that the former is, more sensitive, with good accuracy and precision.

Acknowledgements. - The authors thank the Egyptian pharmaceutical firms (Sedico, Memphis Chemical Co., Pfizer, Medical Union Pharmaceuticals Company and Novartis) for their kind cooperation in providing the raw materials and the formulations used in this study.

\section{REFERENCES}

1. A. G. Kazemifard, D. E. Moore and A. Mohammadi, Polarographic determination of benzaldehyde in benzyl alcohol and sodium diclofenac injection formulations, J. Pharm. Biomed. Anal. 30 (2002) 257-262; DOI: 10.1016/S0731-7085(02)00340-0.

2. M. A. El-Ries, Spectrophotometric and indirect determination of lincomycin by atomic absorption spectroscopy (AAS), Anal. Lett. 27 (1994) 1517-1531.

3. Y. C. de-Micalizzi, N. B. Pappano and N. B. Debattista, First and second order derivative spectrophotometric determination of benzyl alcohol and diclofenac in pharmaceutical forms, Talanta 47 (1998) 525-530; DOI: 10.1016/S0039-9140(98)00080-0.

4. N. Kosmeas and J. T. Clerc, Complete analytical characterization of an antirheumatic injection solution, Pharm. Acta. Helv. 66 (1991) 214-218.

5. K. Urakami, A. Higashi, K. Umemoto and M. Godo, Matrix media selection for the determination of residual solvents in pharmaceuticals by static headspace gas chromatography, J. Chromatogr. A 1057 (2004) 203-210.

6. G. C. Wood, M. R. Iyer, A. M. Geller, A. M. Fleishner and B. B. Sheth, A high pressure liquid chromatography assay method for analysis of deslorelin and benzyl alcohol in deslorelin injection, J. Liq. Chromatogr. Relat. Technol. 21 (1998) 2183-2190.

7. G. N. Menon and B. J. Norris, Simultaneous determination of hydroxyzine hydrochloride and benzyl alcohol in injection solutions by high-performance liquid chromatography, J. Pharm. Sci. 70 (1981) 697-698.

8. United States Pharmacopoeia 27, National Formulary 22, USP Convention, Rockville 2004, p. 2830.

9. British Pharmacopoeia, Her Majesty's Stationary office, London 1998, pp.161-162.

10. K. Urakami, C. Kobayashi, Y. Miyazaki, K. Nishijima and Y. Yoshimura, Degradation products generated by sonication of benzyl alcohol, a sample preparation solvent for the determination of residual solvents in pharmaceuticals bulks, on capillary gas chromatography, Chem. Pharm. Bull. 48 (2000) 1299-1303. 
11. A. G. Kazemifard, D. E. Moore, A. Mohammadi and A. Kebriyaeezadeh, Capillary gas chromatography determination of benzaldehyde arising from benzyl alcohol used as preservative in injectable formulations, J. Pharm. Biomed. Anal. 31 (2003) 685-691; DOI: 10.1016/S0731-7085(02) 00729-X.

12. D. Gormand, J. Brazier, F. Comet and D. Lecompte, High performance liquid chromatographic determination of benzyl alcohol and its degradation product benzaldehyde in a pharmaceutical cream, J. Chromatogr. 355 (1986) 345-349; DOI: 10.1016/S0021-9673(01)97335-2.

13. M. F. Borgerding and W. L. Hinze, Characterization and evaluation of the use of non-ionic polyoxyethylene (23) dodecanol [Brij 35] micellar mobile phases in reversed-phase high-performance liquid chromatography, Anal. Chem. 57 (1985) 2183-2190.

14. I. I. Hewala, Gas-liquid chromatographic and difference spectrophotometric techniques for the determination of benzaldehyde in benzyl alcohol, J. Pharm. Biomed. Anal. 12 (1994) 73-79; DOI: 10.1016/0731-7085(94)80012-X.

15. I. I. Hewala, Difference spectrophotometric assay of benzaldehyde in benzyl alcohol, Talanta 40 (1993) 919-923; DOI: 10.1016/0039-9140(93)80052-S.

16. A. M. Di-Pietra, V. Cavrini and M. A. Raggi, Determination of benzaldehyde traces in benzyl alcohol by liquid chromatography (HPLC) and derivative UV spectrophotometry, Int. J. Pharm. 35 (1987) 13-20.

17. L. J. Love and J. J. Fett, Optimization of selectivity in micellar chromatographic procedures for the determination of drugs in urine by direct injection, J. Pharm. Biomed. Anal. 9 (1991) 323-333; DOI: 10.1016/0731-7085(91)80201-J.

18. J. C. Miller and J. N. Miller, Errors in Instrumental Analysis; Regression and Correlation, in Statistics for Analytical Chemistry, $3^{\text {rd }}$ ed., Ellis-Horwood, New York 1993, p. 115.

\author{
$S A \check{Z} E T A K$
}

\title{
Micelarna tekućinska kromatografska analiza benzilnog alkohola i benzaldehida $u$ injekcijskim pripravcima
}

\author{
MOHAMED RIZK, FAWZIA IBRAHIM, MOHAMED HEFNAWY i JENNY JEEHAN NASR
}

Razvijena je točna, osjetljiva i selektivna reverzno-fazna micelarna kromatografska metoda za simultano određivanje benzilnog alkohola i benzaldehida. Metoda je primijenjena $u$ injekcijskim pripravcima diklofenaka, piroksikama, linkomicina i klindamicina. U koncentracijskom području 10-100 i 1-20 $\mathrm{g} \mathrm{m} \mathrm{mL}^{-1}$ postignuta je izvrsna linearnost, te granica detekcije $(\mathrm{S} / \mathrm{N}=3)$ od $0,25 \mu \mathrm{g} \mathrm{m} \mathrm{L}^{-1}\left(2,3 \times 10^{-6} \mathrm{~mol} \mathrm{~L}^{-1}\right)$ i $0,12 \mu \mathrm{g} \mathrm{mL}-1(1,13 \times$ $10^{-6} \mathrm{~mol} \mathrm{~L}^{-1}$ ) za benzilni alkohol, odnosno benzaldehid. Metoda je uspješno primijenjena za analizu benzilnog alkohola i benzaldehida kao čistih supstancija s analitičkim povratom od $100.1 \pm 1.0 \%$, odnosno $100.4 \pm 1.6 \%$ i u injekcijskim pripravcima $\mathrm{s}$ analitičkim povratom od $99.8 \pm 0.3$, odnosno $100.0 \pm 0.4 \%$.

Ključne riječi: micelarna tekućinska kromatografija, benzilni alkohol, benzaldehid, injekcijski pripravci Faculty of Pharmacy, Department of Analytical Chemistry, University of Mansoura, Mansoura 35510, Egypt 